\title{
Evolution of Entrepreneur Women From Traditional Companies to E-Business
}

Jovanna Nathalie Cervantes-Guzmán, Centro Universitario de Ciencias Económico Administrativas, Universidad de Guadalajara, Guadalajara, Mexico

\begin{abstract}
The need to implement innovations for the growth of SMEs lies in the need to create favorable conditions and the conducive environment for women entrepreneurs to develop the potential of their businesses. The study will be presented from the opinion of the experts composed of founders and CEOs of exponential certified SMEs from developing countries in the artisanal sector. It will expose the tangible and intangible factors that influence decision-making from the perspective of neuroeconomy. The study sets out the opinions of experts, who are decision makers in companies. They were analyzed as they sought to analyze what factors they use to be businesses validated by international NGOs to give them their certification.
\end{abstract}

\section{KEYWORDS}

Behavioral Economics, Decision-Making, Neuroeconomics

\section{INTRODUCTION}

After agriculture, the artisan sector is the second largest employer in developing countries, made up for the most part by women who do traditional crafts to obtain economic resources. These countries have a competitive advantage due to their cultural traditions, artisan skills and specialized raw materials (Foote, 2015).

The artisan sector is a "global creative economy", representing what can be exemplified as a country that would symbolize the fourth largest economy and workforce in the world according to the Inter-American Development Bank (IDB). It is a global industry that generates revenues of \$ 34 billion per year, and only developing countries provide $64 \%$ of global exports, despite this only growing at an annual rate of $4 \%$ (Fonart, 2009).

E-commerce has opened up a new way to directly connect businesses with customers globally by providing new international markets for merchants. In addition, digital technologies are helping businesses expand their sales scales while maintaining their local production, helping to promote the quality and reliability of handcrafted objects, and become part of the new global market trend that focuses on sustainable creation. and ethics through the use of ecological materials generating a high value artisan object (Brown, 2016). Proper management of electronic commerce decision-making will allow artisanal SMEs to increase their competitiveness (Aragon \& Rubio, 2005). 
In the various researches that have been carried out in neuroeconomics so far, none of them at the moment has been carried out that analyzes the factors in the decision-making of certified SMEs of women entrepreneurs in the artisanal sector in their e-commerce, being the emptiness of literature to investigate.

\section{BACKGROUND}

In the statement of the problem, according to the International Telecommunication Union (2015), the internet is used by $43.3 \%$ of the world population, which corresponds to 3,200 million Internet users. The way in which the internet has increased its penetration in the online market has caused changes in the way how businesses interact with consumers, developing e-commerce, causing companies to increase the total number of sales and an increase in online retail interactions of consumers (VanderMeer, et al, 2001). The number of digital shoppers globally is rapidly expanding from 1.32 billion in 2014 to 1,66 billion in 2017 and is expected to increase to 2,14 billion in 2021 (Statista, 2018).

This translates into an increase in electronic sales of global retailers from 2014 by 1,336 billion dollars to 2,290 billion dollars in 2017 and an increase of 4,479 billion dollars is forecast for 2021 (Statistica, 2018). With a participation in the retail e-commerce of 2016 in the regions of Asia and the Pacific with $12.1 \%$, Eastern Europe with 8.3\%, North America with 8.1\%, Central and Eastern Europe with 3.4\% and Latin America with 1.9\% (Statista, 2018).

The population that was analyzed in the research were certified exponential SMEs, being these companies that use and adapt new technologies for their development, modifying their development and distribution model to reduce their growth limitations, being their axis the digital transformation. Joining the new digital trends to sell their products (Ismail, et al, 2014).

These SMEs are found within the cottage industry that has a predominant role in economic development and the fight against poverty, since it is part of the global creative economy that produces the world's largest workforce and generates income of $\$ 34$ thousand million a year according to the Inter-American Development Bank (IDB).

They are run by women entrepreneurs in developing countries, since this industry is mostly made up of women who make traditional crafts to obtain economic resources that $70 \%$ are allocated to the community and family (González, 2016). As women are the key economic agents that produce prosperity, employment, innovation and increased economic development (UN Women, 2016).

These companies are certified by "Artisan Alliance", being one of the main NGOs recognized worldwide. In addition, they work with internationally recognized organizations. They focus on increasing the economic value and sustainable growth of the economically disadvantaged artisan sector to break down the barriers that businesses face to their integration into global trade. This certification being a formal guarantee that companies comply with the universal standards of the criteria by being actively involved in the artisan sector in accordance with the requirements established by UNESCO (United Nations Educational, Scientific, and Cultural Organizations) and ITC (Technological Institute of the Canary Islands) (Artisan Alliance Enterprise, 2016)- In the study their decision making in the digital business will be presented taking into account tangible and intangible factors.

The justification of this research is the need to implement innovations for the growth of SMEs lies in the need to create favorable conditions and the conducive environment for women entrepreneurs to develop the potential of their businesses.

E-commerce offers great potential for the expansion of SMEs to international markets by intensifying sales power by creating a new distribution channel to reach new customers, develop marketing strategies and produce new business opportunities (Colvee, 2013). In addition, e-commerce is a powerful tool that allows SMEs to advance more quickly in the development phases, positioning the company in the world market.

Therefore, women entrepreneurs must use information technologies for their exponential growth. For this reason, the decision-making by businesswomen on the online page and their e-commerce takes 
into account their knowledge and experiences, and these are reflected in the tangible and intangible factors in the digital company.

The following research will expose the opinion of experts made up of founders and CEOs on how they carry out this decision-making in the online business of SMEs in the artisan sector that are certified. Analyzing their tangible and intangible factors that led them to be companies validated by one of the most important international NGOs.

\section{LITERATURE REVIEW}

\subsection{Artisanal SMEs in Developing Countries}

After agriculture, the artisanal sector is the second largest employer in developing countries. Moreover, this sector is mostly made up of women who perform traditional handicrafts to obtain financial stability. The developing countries have a competitive advantage due to their unique cultural traditions, artisanal skills and specific raw materials (Foote, 2015).

The artisanal sector is a part of the global creative economy. It can be exemplified by representing it as a country that would symbolize the fourth-largest economy and labour force in the world, according to the Inter-American Development Bank (IDB). It is a world industry that generates revenues of $\$ 34$ billion per year, with only developing countries providing $64 \%$ of exports worldwide. According to the United Nations Educational, Scientific and Cultural Organization (UNESCO, 2001), it states that the artisanal sector plays a predominant role in the economic development and poverty reduction. In addition, consumption habits and preferences are changing because the customers care about the product's origin, who made it and how the product was manufactured. The customers are changing their preferences for mass-produced goods to the hand-made ones that are original and uniquely designed (INDEGO AFRICA, 2016).

\subsubsection{Challenges of Artisanal SMEs in Developing Countries}

SMEs are a great engine of the Mexican economy. $47 \%$ of such SMEs are run by women, contributing $37 \%$ of GDP and also allocating $70 \%$ of their income back to the community and family unlike male entrepreneurs who contribute between $30 \%$ and $40 \%$ respectively (González, 2016). At the same time, women entrepreneurs experience several challenges that hinder their business growth opportunities, such as the lack of support and skills to achieve the competitive advantage, and the need to balance work and family commitments (Amigón, 2014).

Latin America has the highest rate of business failures of female-run companies. In Mexico alone, 2.2 million formal companies or $17.63 \%$ of the total are female-run. In addition to that, the size of female-run enterprises is $80 \%$ smaller than the ones run by men. For example, women-led companies have less than 15 employees compared to $48 \%$ of ventures run by men. Only $4 \%$ of womenled companies in Mexico have more than 100 employees compared to $17 \%$ of the companies run by men. Also, 50\% of female-led enterprises generate a profit of less than USD 50,000, compared to $25 \%$ of the companies that are run by men (Power \& Magnoni, 2010).

One can also add that the companies in the artisanal sector are small and undercapitalized. They have relatively non-liquid inventories and limited access to financial resources. It is also difficult to sell artisanal products, so these companies are export-dependent (Fellowships, 2016). So these companies have a long way to go to achieve their maximum potential in generating employment and income and, finally, contribute to higher economic growth in developing countries. Producing an opportunity to support artisans with the business skills and technical knowledge they need to maintain and grow their businesses appears to be a necessity. The artisanal sector has a great untapped potential that can generate a higher amount of income and jobs to make a social and economic impact on entrepreneurs worldwide and especially on women (Foote, 2015). 


\subsection{E-Commerce in Artisanal SMEs}

The transformation of commerce and technology in the last decade has modified the way in which individuals acquire and consume goods and services, causing as a consequence a reduction in the costs of international communication and transport. In addition to an increase in immediate demand, so there is a transformation by entrepreneurs to e-commerce to reach the customer (Chakraborty, 2014).

The increase in e-commerce has generated a great impact in third developing countries such as Africa with an increase for 2018 of 42 billion dollars compared to 2013. E-commerce represents a significant change in commerce by representing retail sales in the United States 13\%, Europe 10\%, and an increase in the United Kingdom (EMarketer, 2013). But this figure is lower in developing countries like Africa at 2\% (Almenida, et al, 2007).

Despite its opportunities and benefits, there are a series of barriers that make it difficult for SMEs to access it, such as the high cost of shipping and the cost of entering international markets, having an impact on the profitability of SMEs, lack of internet access as this has become an indicator of wealth. For this reason, the countries have undergone a transformation for the facilitation of trade, such as the simplification of customs duties and low-value departure settlement procedures, causing the reduction of costs in e-commerce (Bansal, 2016).

\subsubsection{E-Commerce in Artisanal SMEs in Developing Countries}

Internet helps the economies of emerging countries to make markets more inclusive and easier to access, it has become an alternative means for business growth by increasing the potential market, being a tool that has the potential to bring together artisans in third world countries and consumers at a national and international level (Kumphai, 2006).

Batchelor \& Webber (2002) mention that the growth of electronic commerce will provide new ways for artisanal SMEs in developing countries to face competition. Their benefits are:

- Through profitable marketing tools they can expand the market reach;

- Reduce operating costs for buyers;

- Get information faster and at lower cost from customers;

- Identify market opportunities with greater speed.

SMEs can be at the same level as a company as long as the use of technologies is correct (Goyal, 2008).

\section{METHODOLOGY}

The collection of information for the company's purchase intention model included data collection through surveys using the modified Delphi method that integrates neuroeconomics to analyze the perception of participants to a series of questions, being used for the development of causal relationships in complex social and economic phenomena.

Delphi method is a technique that combines the quantitative and qualitative method for its application. Its methodology focuses on obtaining information from experts based on knowledge in the industry and the ability to analyze the items appropriate to their area of knowledge (García \& Lena, 2018). This was considered relevant since there was the opportunity to access to a relevant number of experts in the professional and social environment of the object of study.

This was carried out through a literature review of previous works on the subject, using as a basis the investigation of Nada's doctoral thesis (2013) with the topic "Project approval decisions: exploring success factors"; The research analyzes the interaction of decision-makers, taking into consideration executives and project managers through surveys using the modified Delphi method that integrates neuroeconomics. 
This adaptation was carried out through self-administered online surveys using the "Google Surveys" program. The method is made up of a qualitative questionnaire of open questions, applied to experts who have knowledge and experience of the problem to be investigated and are made up of CEOs and founders who are made up of female entrepreneurs who lead exponential SMEs of the artisanal industry in developing countries certified by "Artisan Alliance" (Tables 1-2).

\section{Table 1. Matrix of operationalization of variables}

\begin{tabular}{|l|l|}
\hline $\begin{array}{l}\text { General } \\
\text { objective }\end{array}$ & $\begin{array}{l}\text { 1. Analyze from a qualitative perspective using the modified Delphy method that integrates } \\
\text { neuroeconomics, the opinion of experts of founders and CEOs that are made up of female } \\
\text { entrepreneurs, who run exponential SMEs in the artisanal industry in developing countries that are } \\
\text { internationally certified. }\end{array}$ \\
\hline $\begin{array}{l}\text { Specific } \\
\text { objectives }\end{array}$ & $\begin{array}{l}\text { 1. Expose the tangible factors in the decision making of the entrepreneur in the online business. } \\
\text { 2. Expose the intangible factors in the entrepreneur's decision making in the online business. }\end{array}$ \\
\hline $\begin{array}{l}\text { General } \\
\text { question }\end{array}$ & $\begin{array}{l}\text { What is it like from a qualitative perspective using the modified Delphy method that integrates } \\
\text { neuroeconomics, the opinion of experts from founders and CEOs who are made up of female } \\
\text { entrepreneurs who lead exponential SMEs in the artisanal industry in developing countries that are } \\
\text { internationally certified? }\end{array}$ \\
\hline $\begin{array}{l}\text { Specific } \\
\text { questions }\end{array}$ & $\begin{array}{l}\text { 1. What are the tangible factors in the entrepreneur's decision-making in the online business? } \\
\text { 2. What are the intangible factors in the entrepreneur's decision making in the online business? }\end{array}$ \\
\hline Hypothesis & $\begin{array}{l}\text { H1: Tangible factors are directly related to the entrepreneur's decision-making in electronic } \\
\text { commerce. } \\
\text { H2: Intangible factors are directly related to the entrepreneur's decision-making in electronic } \\
\text { commerce. }\end{array}$ \\
\hline Variables & $\begin{array}{l}\text { Dependent: Decision making by the employer. } \\
\text { Independent: Tangible and Intangible Factors. }\end{array}$ \\
\hline Methodology & Qualitative(modified Dephi method that integrates neuroeconomics) \\
\hline
\end{tabular}

Table 2. Technical file

\begin{tabular}{|l|l|}
\hline \multicolumn{2}{|c|}{ Methodology } \\
\hline Scope of the study & Exploratory - descriptive research \\
\hline Design & Cross- sectional \\
\hline Universe & $\begin{array}{l}35 \text { exponential SMEs of the artisan industry of certified women } \\
\text { entrepreneurs }\end{array}$ \\
\hline Geographical scope & Developing countries \\
\hline Type of sampling & Probabilistic by convenience \\
\hline Sample size & 28 questionnaires \\
\hline $\begin{array}{l}\text { Level of confidence and sampling } \\
\text { error }\end{array}$ & $99 \%,+$ - 12\% \\
\hline Data collection method & Modified Delphi method that integrates neuroeconomics, \\
\hline Fieldwork period & March- September 2019 \\
\hline
\end{tabular}

Source: Own elaboration based on the methodology used in this research. 


\section{ANALYSIS OF THE RESEARCH AND RESULTS}

\subsection{Results of the Qualitative Analysis}

\subsubsection{Common Approach to Make Decisions Online}

Understanding how the customer makes decisions online is critical for the success of the company, the strategy differs from a physical establishment. This is influenced by motivating factors such as the availability of information and unlimited accessibility; and demotivating factors such as the uncertainty of the product quality and the lack of trust due to the lack of direct contact between the buyer and the seller (Lasslop, 2015).

The particular characteristics in the consumer's online purchasing process, according to a Fernández (2014) are:

- Novelty: Lack of experience in buying will generate an increase in internet tools;

- Complexity: Internet a large amount of information that will influence the purchase;

- Perceived risk: Uncertainty in online shopping situations;

- Individual's personal bet: The tools have a positive influence on the online shopping process;

- Time pressure: Internet causes a decrease in the influence of the participation of external individuals in the decision process.

The following quotes present the most relevant information presented by the businesswomen on the subject:

In general, a scientific approach is the norm, following the guidelines of the industry and the market. (Founder and CEO of Merkao)

Research, compare and see trends. (Founder of Hello Crisp)

As it is not a product that can be touched, you have to convince the rational brain to buy the emotional brain. (CEO of Ibu Movement)

\subsubsection{Non-Tangible Factors (Emotions, Feelings, etc.)}

Emotions in online decision-making by the client are of vital importance since $95 \%$ of purchase decisions are made from the emotional sphere. In the process of building a brand, what is most important is the empathy that is generated in the client with their values and philosophy, and what has the least degree of relevance is the product. By transmitting feelings, the brand creates special connections with consumers, since they cause a greater degree of bonding than with rational messages that can become promotional or negative messages. What can generate that a brand can sell up to $23 \%$ more than a brand that does not excite people. (NewsMDirector, 2017)

The following quotes present the most relevant information presented by the businesswomen on the subject:

Working intercultural is always a factor when trends and personalities are coming together. (Manager of ESNET LLC for Village Artisan)

Of course it is necessary to consider the non-tangible factors, people in general buy for emotions. (CEO of Ibu Movement) 


\subsubsection{Project in General (Products and Attributes of the Brand)}

The trust that the brand transmits in customers is important for its positioning in the market. Because companies are aware that it is necessary to achieve company growth, with their generation being the priority of $88 \%$ of marketing specialists. According to Foro Marketing (2019), it is integrated within the technological tools due to credibility, relevance and reliability:

- Credibility: The objective is achieved by transmitting the actions and purpose of the company through the web.

- Relevance: The user's attention is captured by personalizing the experience through original, unique and personalized communication.

- Reliability: Align promises with the company it can offer, meeting customer expectations.

To position the company in the market and differentiate itself from the competition, it must have a distinctive, either in the processes, technology, advertising, the environment, what you sell, etc. The brand must offer a differential and / or a benefit, offering a plus that will cause the customer to remember it forever. This must be communicated clearly visually and not necessarily explanatory, presenting it in a creative way that makes the product distinctive and its benefits (Meza, 2017).

The following quotes present the most relevant information presented by the businesswomen on the topic:

Positioning and image, supporting a cause. (CEO of Finatur Designs)

Reliability that you can transmit, even though the website. (Founder of Hello Crisp)

First, be sure that we have attributes in the brand, look for a differentiator and if there is no need to build it. The differentiator must make sense to the client, if not, as much as it seems "nice" to us, it does not work. The second part is to communicate it with as few words as possible. (Tanya Moss CEO)

Professionalism, reliability, confidentiality and punctuality. (Manager of ESNET LLC for Village Artisan)

I like to encourage new ethical entrepreneurs interested in entering the fair trade and sustainability market. (Founder and CEO of Mortif)

Make our potential client choose us after having seen several pages because we give them confidence. We do not compete on price "ever". (Founder and CEO of Nanay SRL)

\subsubsection{Consumer Satisfaction (Reliability, Commitment, Loyalty, etc.)}

The importance of constant and personal communication with customers through technology is necessary to improve online reputation and promote theirself to expose an updated brand and present a positive image on the internet (Maderuelo, 2012).

The accessibility generated by the online world allows customers to have an interconnectivity to consult and issue an opinion about a product. This exchange of information and experiences allows the consumer to know the quality of the product, the competitiveness of the price and verify the validity of the offer, increasing their negotiating power and influence to a greater virtual community in contrast to the exposure they would have in a traditional store which is only limited to your direct contacts. This causes greater pressure on online channel sellers to position their brand in the market (Lasslop, 2015). 
The following quotes present the most relevant information presented by the businesswomen on the topic:

Our goal is to maintain regular communication with our buyers through emails and newsletters. (Founder and CEO of Mortif)

Our communication is very personal with each of our clients to help build relationships. This is the key to the return business. We monitor consumer satisfaction and ask them for suggestions to have a greater added value. (Founder and CEO of Merkao)

Reliability is the key that supports the long term. The access to personal attention of a human being, even if it is technology, allows raising the level of customer satisfaction. In all things digital, the customer openly expresses his comments and these have repercussions on other potential buyers. (Manager of ESNET LLC for Village Artisans)

\subsubsection{Characteristics of the Web Page (Design, Appearance, Clarity of Information, etc.)}

The design and ease of navigation on the web page is important to attract a greater number of customers. Because it represents the user experience, which is integrated by the ease of finding the content and the sections that make it up are attractive. Being the showcase of the online store, so to get customers to see the products you must have the best web development that allows them to feel comfortable. Being relevant for the growth of a company, since $57 \%$ of users do not recommend an online page because the experience did not exceed expectations (MAS Digital, 2015).

The following quotes present the most relevant information presented by the businesswomen of the topic:

Page with attractive and concrete design, friendly, clean and intuitive for navigation, information, photographic quality, use of videos, brand history. (Founder and CEO of Nanay SRL)

Less is more. It is important that it has the fewest possible clicks, that it is oriented to what the client needs to know and that it has means of immediate contacts to expand the information if necessary. (Founder of Amano Artisans)

Have a common goal, how you want to express your business on your website, that you want to express to your potential client. We are about to update our website to be aligned with the constant changes in the business world. (Founder and CEO of Merkao)

The website is a means of contact, where each product has to have its own landing page with key information (short, concise and precise) and automated means of purchase and payment. (CEO of Ibu Movement)

5.1.1.5. Most Important Factors in the Information Contained in the Web Page to Achieve the Success of the Company

Current advertising requires new tools that captivate an audience that is oversaturated with traditional advertising and that generates a link with the consumer, being storytelling an effective marketing tool (Guisado, 2017).

Storytelling as a differentiating factor in companies, integrating the people who make it up as the social impact they generate. These create emotional links, generating a deep connection between the brand and the client, by telling authentic stories linked to a real message that exposes the origin and 
its growth, always taking care of its narrative. These are memorable because they remain in people's minds for longer (Puro Marketing, 2018).

The following quotes present the most relevant information presented by the businesswomen on the topic:

The story of the women who make up the brand in Guatemala. (Founder and CEO of DIOSA designs inc.)

The most important factors are integrated by the history behind the company, the people involved in the production since many buy in favor of the people who are affected, the equity in prices so that they are respected by both customers and to the producers. (CEO of Handcrafts and Cultural Foundation of Uganda)

Simple interface for the user, beautiful product photography, quality information, history about our products, the processes, our team and the artisans that comprise it. (Founder and CEO of Mortif)

The social impact of our work and Fair Trade. (CEO of Finatur Designs)

The history of the producers, the social impact of the company and good marketing. (Founder and CEO of Nanay SRL)

\subsubsection{The Adoption of E-Commerce Will Provide Timely and Accurate Information for Decision-Making}

The information available on the website to facilitate customer decision-making, according to Antevenio (2016) must be:

- Adequate product file: Provide the user with the information they need in their description, such as: operation, composition, clear graphic image and availability. Because unlike a physical store where you can touch the product, in this there is no physical interaction.

- Personalized search: Filters on the page provide a better user experience because they save time and generate convenience.

- Sales form: These should be self-explanatory and simple at the time the user makes the purchase process.

- Comments from other customers: It is one of the factors that have a greater influence on making a purchase decision, so the company must be aware of post-purchase rationalization.

The following quotes present the most relevant information presented by the businesswomen on the subject:

It is a different model from that of traditional organizations. The tools available today for better decision making and the use of information are an advantage. (Founder and CEO of Merkao)

Provide enough information for a purchase to be made, so that people can make an informed decision. The more information, the more accurate decision-making. (Sprout Enterprise CEO)

Women helping women around the world is my motto. Busy professional women need to make quick and informed decisions, but they want to feel good about buying something fashionable, versatile, and worth the money they pay for it. (Founder and CEO of DIOSA designs inc.) 


\subsubsection{E-Commerce Will be Compatible With the Strategic Objectives of the Organization}

E-commerce is an important tool for the growth of a business because those who have implemented it have experienced an increase in their sales. This is caused by the 24/7 openness, the increase in the breadth of markets at national and international level and the high value that the consumer gives it. Electronic commerce transformed the way products are marketed by modifying the rules of the game in the market, providing a greater development opportunity for SMEs (Open Ideas, 2019).

Currently, SMEs are integrating information technologies (ICTs) as an integral part of the activities of companies, with electronic commerce being a vitally important tool to market more quickly and grow the business (Figueroa, 2015).

The following quotes present the most relevant information presented by the businesswomen on the subject:

Yes, because we want more people to be aware of fair trade and its impact. (Founder and CEO of Mortif)

My strategic objectives are to achieve a broad market coverage and increase production, and e-commerce serves that purpose. (CEO of Handcrafts and Cultural Foundation of Uganda)

We want to sell products and tell our story. Our online platform allows us to do it. (CEO of Sprout Enterprise)

It allows us to interact with a wider market and increase our sales. To introduce my brand in international markets without having the budget of a transnational, the best way to do it is through e-commerce. (Founder and CEO of Atellier)

Yes, because it is the strongest tool to grow. (CEO of Tanya Moss)

\subsubsection{E-Commerce Will be Compatible With the Values and Beliefs of the Organization}

Fair trade as a belief of the company because it is part of a solidarity and social economy, because it is integrated by practices that are based on transparency and access to information. Taking as a criterion the application of a fair and equitable price, commercial transparency, mutual respect and ethical values for the search for a common good, generating the conditions for a sustainable development that regulates the failures of the current capitalist system (García, 2011).

The value of e-commerce support for artisans allows entering a business model that offers a sales and export channel, providing the opportunity to reach new consumers at a national and international level (Velázquez, 2018).

The following quotes present the most relevant information presented by the businesswomen on the topic:

The fact that we promote culturally inspired products and craft skills will be directly supported and promoted as an ethics of the organization. (CEO of Handcrafts and Cultural Foundation of Uganda)

Yes, our online store allows us to present the artisan companies that produce our products. It's not just about the product. (CEO of Sprout Enterprise)

Promoting our fair trade goods to a wider audience increases awareness and creates more ordering opportunities and thereby increases the work of our artisans. (Founder and CEO of Mortif) 
Electronic commerce is a business carried out through the internet, it employs human beings and as such must have a set of values that are practiced by all employees. (CEO of Ibu Movement)

Yes, you can be Fair Trade and increase opportunities for artisans to increase their income. (CEO of Finatur Designs)

Yes, because it is built in a way that reflects our values. (Founder and CEO of Merkao)

\subsubsection{E-Commerce Will be Compatible With Past Experiences and History of the Organization}

E-commerce as a business transformation process involves changes at all levels of internal and external activities, generating a conversion between the traditional and technological aspect of the company, providing the opportunity to adapt the company to current market needs (Rocamora, 2017).

Because today society is highly technical and they have access to a spectrum of abundance through a market that requests a wide variety of products and technology is a means to satisfy their demands (Guerrero \& Rivas, 2005).

The following quotes present the most relevant information presented by the businesswomen on the subject:

Our company was established to contribute to the economic and social transformation of marginalized people. After our history, electronic commerce will be compatible since it will promote the products of of groups of artisans. (CEO of Handcrafts and Cultural Foundation of Uganda)

Yes, we have always sought to publicize fair trade alternatives and increase work for our artisans. (Founder and CEO of Mortif)

E-commerce is done day by day, and every day it is built, it definitely has to see the past, but just as you mature as a person you have to mature as a company. (CEO of Tanya Moss)

\subsubsection{Will E-Commerce be Compatible With the Organization's Requirements?}

Electronic commerce is the next stage in the evolution of SMEs, as it has a direct correlation between the implementation of e-commerce and the profitability of the company, as it is an information technology tool that allows greater interaction and communication with the market, increasing productivity and competitiveness by generating greater brand visibility and reduction in transaction costs. By allowing SMEs to advance to a higher level the development phases, this contributes to developing economies having greater benefits (Sanabria, et al, 2016).

The following quotes present the most relevant information presented by the businesswomen on the subject:to carry out:

The requirements economic and social transformation, electronic commerce is a global platform for the organization to be more compatible with market requirements. (CEO of Handcrafts and Cultural Foundation of Uganda)

To grow there has to be more income and e-commerce is an opportunity to generate it. (Founder and CEO of Mortif)

It will help my organization to continue progressing. (Founder of Atellier)

\subsection{Results}

The results are discussed in Table 3. 
Table 3. Results of the entrepreneur's decision making in the online business

\begin{tabular}{|c|c|c|}
\hline & Tangible Factors & Non-tangible Factors \\
\hline \multirow{9}{*}{$\begin{array}{l}\text { Decision on the online } \\
\text { page }\end{array}$} & Scientific focus on industry and market guidelines & Emotions \\
\hline & Social impact of the company & Cultural factors in trends \\
\hline & Establish functional attributes of the brand & Positivism \\
\hline & $\begin{array}{l}\text { Website with attractive and concrete design, ease of } \\
\text { navigation and key information about the company }\end{array}$ & Satisfaction \\
\hline & Storytelling of the brand & Reliability \\
\hline & Show the team and craftsmen that make up the company & Professionalism \\
\hline & Adaptation to the constant changes in the market & Confidentiality \\
\hline & & Communication \\
\hline & & Customer opinion \\
\hline \multirow{8}{*}{$\begin{array}{l}\text { Importance of e-commerce } \\
\text { in the company }\end{array}$} & Transformation and evolution tools & Dissemination of information \\
\hline & Greater market coverage & Growth \\
\hline & Transmission of the company's history & Awareness \\
\hline & Increase in sales & $\begin{array}{l}\text { Reflection of personal and } \\
\text { business values }\end{array}$ \\
\hline & $\begin{array}{l}\text { Global platform for the company to adapt to market } \\
\text { requirements }\end{array}$ & Evolution \\
\hline & Diffusion of artisan skills & $\begin{array}{l}\text { Personal and business } \\
\text { maturation Product }\end{array}$ \\
\hline & promotion & Progress \\
\hline & Economic and social transformation of artisans & \\
\hline
\end{tabular}

Source: Own elaboration

\subsection{Success Story Using the Knowledge Expose in This Research}

Atellier Organic Joyas de Autor makes jewelry, with handcraft designs, handmade, with ecologic process and semiprecious stones from local suppliers of the LATAM's mines.

Fashion designer Patricia Guzman Robledo, being a single mother, facing the difficulties of gender equality in the professional field in a developing country, decides to undertake with her daughter Jovanna Nathalie Cervantes Guzman. Initiating in the dining room in their house a brand focused on the ecology and support women.

With the implementation of the knowledge and information in this research, Atellier Organic. Joyas de Autor is an award-winning brand, is internationally certified, is a member of international NGOs, has been a finalist in national contest and winner of the "Women and Business Contest" at "Pacific Trade Show" in Toronto, selected in the program "Young Leaders of the Americas (YLAI) 2020 by the US embassy, gives mentorship to women entrepreneurs in developing countries in NGOs, and sells their pieces through recognized online stores.

\section{LIMITATIONS AND FUTURE RESEARCH DIRECTIONS}

In this article, the use of any neuroscience technique was not involved, which cannot fully illustrate this particular aspect of the model regarding our current study. 
Within the limitations of the thesis are that it is not a parametric statistic, because to perform a parametric analysis it must start from the following assumptions:

1. The population distribution of the dependent variable is normal: the universe has a normal distribution;

2. The level of measurement of the dependent variable is interval or ratio;

3. When two or more populations are studied, they have a homogeneous variance: the populations in question have a similar dispersion in their distributions.

\section{CONCLUSION}

The factors that affect decision-making are different, they may be affected by some particular characteristics such as gender, environmental factors and age. Gender in decision-making, women have a greater aversion to risk due to the high level of cortisol, while men have a greater propensity to trust due to the high level of testosterone. Environmental factors in decision-making that cause a decrease in sales and a reduction in prices are influenced by various aspects such as lunar cycles, light intensity and geomagnetic storms (BBVA, 2011). Age influences decision-making since the reduction in the production of dopamine and serotonin decreases as a person ages, having less effect on the appreciation and receipt of the reward, in addition to the assumed risk (Mohr, et al, 2010).

In relation to the objective of the research, it was found that the non-tangible aspects are necessary for emotions to project a positive internal and external image for the management of the business. But they have to adapt to tangible aspects such as adaptation to consumer needs, market requirements and the use of technology, without neglecting the history of the brand, how it is represented, and the importance of social impact, to achieve growth and evolution towards a global platform that generates greater market coverage. 


\section{REFERENCES}

Almenida. (2007). Promoting E-Commerce in Developing Countries, Internet Governance and Policy Discussion Papers. DIPLO. Retrieved from http://archive1.diplomacy.edu/pool/fileInline.php?IDPool=454

Antevenio. (2016). 10 factors that influence the decision to buy online. Antevenio Anticipation e-marketing. Retrieved from https://www.antevenio.com/blog/2016/10/10-factores-que-influyen-en-la-decision-de-compraonline/

Artisan Alliance Enterprise. (2016). Impact Report. Alliance for Artisan Enterprise.

Bansal, S. (2016). Cross-border online shopping gains traction. Live Mint. Retrieved from https://www.livemint. com/Opinion/Q2Tdjh825pXp87j4M7QT9M/Crossborder-online-shopping-gainstraction.html

Batchelor, S., \& Webb, M. (2002). E-commerce options for third worlds craft productions. UK Department for International Development. DFID.

BBVA Innovation Center. (2011). Neuroeconomics: Brain mechanisms involved in financial decision making. KnowSquare: Knowledge Network.

Brown, J. (2016). Making it local: what does this mean in the context of contemporary craft? Council Craft.

Chaudhuri, A., \& Holbrook, M. (2001). The chain of effect from brand trust and brand affect to brand performance: The role of brand loyalty. Journal of Marketing, 65(2), 81-93. doi:10.1509/jmkg.65.2.81.18255

Colveé, J. (2013). Practical guide to e-commerce for SMEs: first steps towards success. Anetcom Editions. Retrieved from http://video.anetcom.es/editorial/GUIA_E-COMMERCE_BR.pdf

Digital, M. A. S. (2015). Why is the browsing experience important on a web page? Masdigital. Retrieved from https://www.masdigital.net/nuestro-blog/por-que-la-experiencia-de-navegacion-es-importante-en-una-paginaweb

EMarketer. (2013). B2C Ecommerce Climbs Worldwide, as Emerging Markets Drive Sales Higher. Retrieved from https://www.emarketer.com/Article/B2C-Ecommerce-Climbs-Worldwide-Emerging-Markets-Drive-SalesHigher/1010004

Fernández, L. (2014). Online consumer behavior: factors that increase ewom's search activity in the tourism sector (Master's thesis). University of Oviedo, Oviedo, Spain.

Figueroa, E. (2015). Profitability and use of electronic commerce in micro, small and medium-sized companies in the commercial sector. RIDE Ibero-American Journals for Educational Research and Development, 6(11).

FONART. (2009). Manual of Differentiation between Crafts and Crafts. Retrieved from https://www.fonart. gob.mx/web/pdf/DO/mdma.pdf

Foro Marketing. (2019). Trust as the central axis of the relationship with the consumer. Marketing.com Forum. Retrieved from https://www.foromarketing.com/la-confianza-eje-central-la-relacion-consumidor/

García, J., Garcia, R., Hernández, F., López, V., \& Núñez, M. (2017). BidData: One click away from ICTs. Telefonica. Retrieved from https://aunclicdelastic.blogthinkbig.com/wp-content/uploads/eBook-BIG-DATAAunClicdelasTIC.pdf

García, M., \& Lena, F. (2018). Application of the Delphi method in the design of a quantitative investigation on the FABLAB phenomenon. EMPIRIA. Journal of Social Sciences Methodology, 129-166.

González, M. (2016). 31\% of the national GDP is contributed by women entrepreneurs. Report BTL. Retrieved from https://www.informabtl.com/31-del-pib-nacional-es-aportado-por-mujeres-empresarias/

Goyal, A. (2008). The impact of ICT in making global markets more inclusive. Indian Institute of Management Bangolore, 20(4). Retrieved from https://www.iimb.ac.in/publications/review/december2008/impact-ictglobalmarkets

Guerrero, R., \& Rivas, L. (2005). Electronic commerce in Mexico: proposal of a conceptual model applied to SMEs. International Journal of Social Sciences and Humanities, 15(1). Recovered from https://www.redalyc. org/pdf/654/65415104.pdf 
Guisado, A. (2017). Storytelling: how storytelling helps marketing strategy (Master's Thesis). University of Seville, Seville, Spain.

Insmail, S., Malone, M., \& Van, Y. (2014). Exponential Organizations: Why there are new organizations ten times more scalable and profitable than yours (and what you can do about it). Singularity University Book.

International Telecommunication Union. (2015). Measuring the Information Society Report. ITU.

Kumphai, P. (2006). Cultural products: definition and website evaluation (Doctoral thesis). Oklahoma State University.

Lasslo, J. (2015). Influential factors in the consumer's purchase decision in B2C e-commerce (Bachelor's thesis). Comillas Pontifical University. Retrieved from https://repositorio.comillas.edu/jspui/bitstream/11531/4586/1/ TFG001362.pdf

Maderuelo, E. (2012). The importance of the company’s online communication. Comunic @ rte. Retrieved from http://esthermaderuelo.com/la-importancia-de-la-comunicacion-online-en-la-empresa/

Meza, A. (2017). Silver skin: brand differentiators. Forbes Mexico. Recovered from https://www.forbes.com. $\mathrm{mx} /$ piel-plateada-diferenciadores-de-marca/

Mohr, P., Biele, G., \& Heekeren, H. (2010). Neural Processing of Risk. Journal of Neuroscience. Vol, 30(19), 6613-6619. doi:10.1523/JNEUROSCI.0003-10.2010 PMID:20463224

Nada, D. (2013). Project approval decisions: exploring success factors ( $\mathrm{PhD}$ thesis). University of Calgary.

NewsMDirector. (2017). Why use emotions in your digital marketing strategy? M Director. Retrieved from https://www.mdirector.com/marketing-digital/emociones-en-marketing-digital.html

Open Ideas. (2019). The importance of e-commerce for the growth of consumer electronic companies. Openideas. is. Retrieved from https://www.open-ideas.es/ecommerce-crecimiento-empresas/

Puro Marketing. (2018). The importance of storytelling: Because the company needs to have a founding story. PureMarketing. Retrieved from https://www.puromarketing.com/55/30323/importancia-storytelling-empresanecesita-tener-historia-fundacional.html

Rocamora, J. (2017). Digital transformation: how to integrate e-Commerce into your traditional business. Marketing4commerce. Recovered from https://marketing4ecommerce.net/transformacion-digital-como-integrarel-ecommerce-en-la-estructura-de-tu-negocio/

Sanabria, V., Torres, L., \& López, L. (2016). Electronic commerce and level of sales in the MSMEs of the commerce, industry and services sector of Ibagué. EAN University. Retrieved from https://www.redalyc.org/ jatsRepo/206/20645903010/html/index.html

Statista. (2018). E-commerce share of total global retail sales in 2016, by region. The Statistics Portal. Retrieved from https://www.statista.com/statistics/239300/number-of-online-buyers-in-selected-countries/

Statista. (2018). Number of digital buyers worldwide from 2014 to 2021 (in billions). The Statistics Portal. Retrieved from https://www.statista.com/statistics/251666/number-of-digital-buyers-worldwide/

Statista. (2018). Retail e-commerce sales worldwide from 2014 to 2021 (in billions US dollars). The Statistics Portal. Retrieved from https://www.statista.com/statistics/379046/worldwide-retail-e-commerce-sales/

VanderMeer, D., Dutta, K., \& Datta, A. (2012). A Cost-Based Database Request Distribution Technique for Online e-Commerce Applications. Management Information Systems Quarterly, 36(2), 479-507. doi:10.2307/41703464

Velázquez, K. (2018). ProMéxico and Amazon sign agreements to support Mexican SMEs through eCommerce. Marketing4ecommerce.

World Economic Forum. (2009). Global Gender Gap Report. Retrieved from http://iberpyme.sela.org/aDocs/ Desarrollando_Mujeres_Empresarias_PYMES.pdf 